北海道対がん協会検診センター放射線科 ○佐々木秀典・中島玲子・村由 薰 斉藤文男・鈴木章二・速水宏行

[目的]今回われわれは，胃X線写真上の病変示現能 を, 理解するための一手段として，胃病変ファントムの 試作を行い，有效な成果を得られたのて，報告する。

[結果] (1)今回，試作ファントム亿硫酸バリウムを付 着させ, 素早く撮影すると,タマり像,八ジキ像，接線 像を，臨床X線写真に近く表現てきる.

(2)色々な型の病変を試作するしとにより，病変示現能 を, 理解するのに有効である。またX線撮影システムな どの比較にす有用であると考える。

38. 自作補供フィルタを使用した胸部断層撮影の試み 勤压協札幌病院放射線空

○関西 功 - 安藤芳克

胸部断首写真において肺野以外の肺門，縦隔心臓と重 なり合う部位等における情報量を増やすととを目的とし て, 当院です手軽に使用できる補償フィルタを工夫，作 成してみたＸ線管球の前面におけて，フィルタを適当 な振幅で振動させるととにより，フィルタの陰影を除去 し，他方適当な幅で濃度移行部6設定するととができ， 実際の胸部断層撮影飞おいても良好な成續を得るととか できた。 同時にファントムを用いた実験結果に基ずき， フィルタ使用による線質の変化が，写真におよばす影響 についても簡単ではあるが検討をしてみた。

質問 (1)フィルタの間隔は可変できるのか.

(2)人によって縦隔，心蔵の形態力違うと思うがとうい う方法でフィルタ位置を設定しているのか.

答（1)補償フィルタをネゲで固定しているので間隔は 調節可能です。実際には $2 \sim 3$ 種のフィルタを作成して それを使い分けている.

(2)他の補償フィルタの使用経験を参考にして行ってい る.

質問 フィルタ使用による，被曝線量はどう変化する

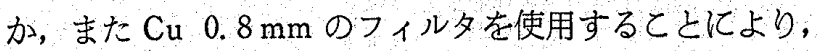
末しょう血管の陰影が消失するようなととはないか，ま たフィルタ透過後の線質を求めているか.

答 線質の変化については使用電圧領域では肺野の陰 影 (血管気管支等) が消失するととはく、むしろ肺野 外周部まで読影できる写真が得られる。被曝線量につい ては (胸骨部, 背柱部の表面) 増加するものの, この点 についての評価は検討していません。

\section{9. 拡大ステレオ線管球用楕円形ツーブスの試作} 北海道大学医学部附属病院放射線部 ○他 知保 - 石川秀司・佐賀和高
坪田秀一 - 菊池 務

近年, 払大ステレオX線管の開発か淮み，その機構的 精度や立体観, 像の歪子等技術的な評価や臨床面での有 用性の評価等, 種々研究発表が成されている。しかしま だくつかの問題点が残されている.

管球内で焦点が移動するため，各々の焦点の位置で照 射野を完全に絞り达むととが現在のコリメータでは不可 能なとともとの一つである.

これは焦点外 X線や幾何学的不鋭による散乱線含有率 の増加，および画質の低下をまねくしとになる.

そとて臨床上許される最小限の絞りをもつ棈円形のッ ーブスを試作し，画質の改善について検討した，結果は 十分とはいえないが画質の向上か認められた。また，改 良型コリメータについても検討を加えた。

40. 脳血管模型の試作

札幌医科大学附属病院中央放射線部 ○小田原好宏・坂田元道 板東道夫・才川恒彦

現在, X線管球，増感紙，フィルム等の改良によりX 線写真のより細部にわたる読影が行われるようになり， われわれに対する要求すX線写真に対するととばかりで なく，局所解剖学的知識を必要とする事も多くなってき た.

われわれは，頭部における脳の立体的知識および局所 解剖学的知識を学ぶために，脳血管模型の製作を試み， 上記の知識を得るため，または，学生の教育に対し非常 に有效たったので報告した。

RI-3 インビトロ (データ処理)

座長 柏木茂喜 (北海道立小韭総合保健センター)

41. 4-PARAMETER LOGISTIC 関数の収束性の拡張 並びに応用回帰分析

旭川医大病院放射線部

○西部茂美・石川幸雄

logit log 1 次多項式の改良法として Rodbard らが報 告し, 最近広く用いられている6のに 4 係数 logistic 曲 線がある. Bo こ NB が回㷌係数として扱われているた め，それらの䛊差が回帰によりうまく是正できる点です ぐれているが，ある種のデータ特に低い高濃度でカーブ のスロープが緩やかな場合は，収束性にも限界がある。 初期值の設定等を改良する事により，収束性は大い搪 大され，かつ分散分析法を用いて回帰式の適分度の判定 とし RIAのデータ処理への応用とした.

42. SPLINE 関数の異常屈曲点に対する柔軟性の検討 （第 1 報）

旭儿医大病院放射線部 ○西部茂美 